\title{
Landscape and Hunting. The Economy of the Eschatia
}

\author{
Christy Constantakopoulou \\ Department of History, Classics and Archeology, Birkbeck College, Malet Street; London WC1E 7HX, UK; \\ c.constantakopoulou@bbk.ac.uk
}

Received: 29 June 2018; Accepted: 23 July 2018; Published: 26 July 2018

\begin{abstract}
This paper explores the place of ancient Greek hunting within the Greek landscape and environment, with particular reference to the eschatia, the marginal, uncultivated (or marginally cultivated) land. It is part of a bigger project on the social history of hunting in archaic and classical Greece, where emphasis is placed on the economic and dietary contribution of hunting for Greek communities. Hunting has attracted scholarly attention, mostly as a result of the role that hunting narratives play in Greek mythology, and the importance of hunting scenes in Greek art. Rather than talking about the role of hunting in rites of passage, I would like to explore the relationships of different social classes to hunting (which is understood here to include all forms of capturing animals on land, including trapping and snaring). The 'un-central' landscape of the eschatia appears to be an important locus for hunting practices, and therefore, a productive landscape. Hunting in the eschatia was opportunistic, required minimum effort in terms of crossing distances, allowed access to game that could be profitable in the market, and made the transport of game easier to manage.
\end{abstract}

Keywords: hunting; eschatia; bird hunting

\section{Introduction: The Greek Polis, the Environment and Ancient History}

The history of the archaic and classical Greek world (8th-4th century BCE) has been traditionally seen as the history of a specific state formation: that of the polis. A Greek polis, or city-state, was understood as a community of people (adult male citizens) that exercised sovereignty over a specific territory. This focus on the Greek polis has important repercussions for how we understand the Greek world, how we write the history of the Greek world, and how we teach this history in our institutions. Indeed, if one looks at the syllabi of modules addressing the history of the Greek world in the archaic and classical periods in UK universities (of which I am more familiar), they will see a focus on the history of the polis, with particular emphasis on the history of a handful of poleis, especially classical Athens. In that, the ancient polis, and especially Athens, has been accorded a central place in our historical narratives. This is partly due to the nature of our written evidence for the classical period, which overwhelmingly originates from Athens or addresses the history of that city. But what about the rest of the Greek world, or the often neglected constituent element of the polis, that is, its landscape?

One of the most important recent developments in the field of Ancient History in recent years is the increasing attention paid to the role of the landscape as an important factor shaping human experiences, activities, and culture. In this respect, ancient historians are probably slightly late in adopting developments that have a longer trajectory in the field of Classical Archaeology. The impact, for example, of landscape surveys on our understanding of ancient material culture has been tremendous, and grows yearly with new archaeological fieldwork taking place. I would highlight as a turning point for the importance of landscape, and the environment in ancient history narratives, the publication in 2000 of Horden and Purcell's The Corrupting Sea [1]. The book's emphasis on the Mediterranean environment as one characterized by geographic fragmentation and increased 
maritime connectivity, which minimized risk posed by environmental factors, has truly transformed our discipline. The other major contribution of that approach was a shift from historical narratives of essentially urban conglomerations, which, for the Greek world, inevitably meant the world of the polis, to historical narratives that look at the landscape and the environment as the space where human activity should be explored.

This is my starting point: an increasing need for ancient historians to explore the history of the Greek world beyond the history of the major urban centres, the poleis [2]. Ancient historians of social history have long recognized the need to look at social groups beyond the adult male citizen: women, slaves, and foreigners are now at the heart of much exciting new work in ancient Greek history. Indeed, one of the most fruitful, in my opinion, developments in this respect is the adoption of intersectionality as an important new approach used to explore social groups [3]. We need to adopt the same diverse outlook when we explore the geography of the Greek world: we need, in other words, to move beyond the history of Athens, Sparta, and the other poleis and their elite male citizens. The history of the Greek landscape and its uses by communities and groups that go beyond the adult male citizen of the Greek polis is a fascinating history that can enrich our understanding. One problem that I will explore further below is the limitation of our written sources, which, on the whole, focus on the elite male citizen and his experience. But I think that a careful examination of the evidence allows us to explore the non-elite point of view. We are used in ancient history to writing narratives from scraps and fragmentary evidence: the lack of explicit sources should not be seen as a hindrance.

\section{Ancient Greek Hunting beyond the Elite}

Writing a social history of ancient Greek hunting allows us to combine a focus on the landscape and its uses, with an interest in social groups beyond the adult male citizen. We are fortunate in that we have plenty of ancient literary and iconographic sources for Greek hunting in the archaic and classical periods. Primary amongst the literary evidence are the so-called 'hunting manuals' written by ancient authors. Of this particular genre, Xenophon's and Arrian's works are probably the best known [4]; we also have the later works by Oppian, Nemesianus, and Grattius [5]. These literary works offer detailed information about ancient hunting. The main focus, however, is what I would call elite hunting, that is, the hunting of mammals, especially hares, often using dogs. Hunting dogs could be very expensive and sought after, as the anecdote of Alcibiades' dog in Plutarch reveals [6]. Indeed, Xenophon's Cynegeticus spends considerable time discussing the appropriate use of different breeds of dogs for different types of hunt. This type of hunting, which also often included the use of horses, primarily concerned the elite. The hunting of hares using dogs or the hunting of boar and deer (often on horseback) is better understood as a pastime or hobby (or indeed even sport) rather than as a necessary activity for the acquisition of meat. On the other side of the evidence spectrum, we have the iconographic evidence on pottery. Such evidence includes many depictions of hunting; these depictions, however, mostly concern mythical narratives, such as the hunt of the Calydonian boar, rather than actual hunting practices [7]. The mythical depictions of hunting may be rooted in the actual hunting experience of the audience of this iconography, but still, such iconography relates to elite hunting practices. So the majority of both literary and iconographic evidence relates to elite hunting experiences, and includes depictions of hunting primarily of boar, deer, and hare.

This feature of our sources, that is, its elite preoccupation, has influenced modern approaches to Greek hunting. On the whole, modern works focus on the type of hunting that ancient sources talk about, that is, the hunt mostly by elite men of deer, boar and hare [8]. The role of hunting as preparation for the (young) elite men to become full citizens and warriors is also the focus of much recent work. This approach, which sees myths about hunting as versions of rites of passage, has been extremely influential, especially in works interpreting iconographic depictions of hunting and the use of hunting as allusions for homosexual relationships [9]. Yet, while such a structuralist approach has enriched our understanding of myth and its relationship with social practices, it is less useful as a way of understanding the social practice of hunting beyond the elite male point of view. 
Despite the ancient and modern preoccupation with elite hunting, there is a plethora of evidence that may be able to help us write the history of hunting beyond the elite. Such a social approach to ancient Greek hunting situates hunting practices within the landscape of the Greek world, and considers it not as an elite pastime but as an important contribution to the alimentary needs of the community. My definition of hunting includes all methods for the capture of animals on land, including trapping, snaring, and netting. It is very likely that such forms of hunting are not pre-eminent in the hunting manuals and main literary sources of the classical period, because they did not promote the kind of male morality and ideology that big game and hare hunting seem to have promoted. A passage from Plato's Laws $(824 a-c)$ provides an illuminating example of this attitude. The Athenian stranger in the passage here presents the ideal city's legislation in relation to hunting; in doing so, Plato openly disapproves of fishing and angling, as well as setting traps, hunting at night, or hunting at the edges of cultivated land, as these forms of hunting do not elevate men [10]. According to the legislator in the ideal city, "only the best kind of hunting is allowed at all-that of quadrupeds, which is carried on with horses and dogs and men's own persons, and they get the victory over the animals by running them down and striking them and hurling at them, those who have a care of godlike manhood taking them with their own hands" (824a). In other words, Plato allows only the form of hunting that the elite practised: that of quadrupeds on land with horses and dogs, and not any form of capturing animals by traps, nets, or snares. Plato fully articulates here the implied bias against other forms of hunting that exists in Xenophon's writing. But, as mentioned previously, despite this ideological position of ancient authors, there are a number of indicative references to nets, traps, and snares, which, as Plato's legislation implies, must have been common practice for capturing animals on land (which therefore made Plato include them in his legislation). It is to these references we now turn.

\section{Netting, Trapping and Snaring: The Evidence from the Epigrams}

A number of funerary and dedicatory epigrams from the Palatine Anthology (a late Byzantine compilation of epigrams, including many from the Hellenistic period) refer to nets, traps, and other equipment used in hunting animals. Such references are indeed numerous, so I will only discuss a handful of examples [11].

A funerary epigram for Eumelus, written by Isidorus of Aegae in the first century BCE (7.156), is typical of the genre of epigrams referring to hunting equipment:

'By his bird-lime and canes Eumelus lived on the creatures of the air, simply but in freedom.

Never did he kiss a strange hand for his belly's sake. This his craft supplied him with luxury and delight. Ninety years he lived, and now sleeps here, having left to his children his bird-lime, nets, and canes' (translation by W.R. Paton). [12]

This example uses some typical elements of a funerary epigram: the deceased died old and lived in idealized autarchy and freedom. What is interesting for our purposes is the allusion to bird-lime, nets, and canes. These were used for the hunting of birds; indeed, this type of hunting would not have been allowed in Plato's ideal city, as it did not involve the pursuit of quadrupeds on land. Similar themes can be found in two further funerary epigrams included in the Anthology: that by Mnasalcas of Sicyon (7.171) and by Antipater of Sidon (7.172). In both epigrams, the deceased appears to have hunted birds, using sticks with bird-lime in the first and slings in the second.

It is the dedicatory epigrams included in book 6 of the Anthology, however, where more references to nets, sticks, traps, and bird-lime can be found. An epigram by Antipater describes the huntsman Craugis' dedication of nets, snares, traps, cages, nooses, stakes, canes, and cords to Pan the Scout (skopietas) (6.109) [13]. The list of equipment used in hunting is truly impressive and implies a specialized practice targeting birds. Another dedicatory epigram written by Philip of Thessalonike mentions the dedication of a spear, nets, nooses, and traps (6.107) [14]. The dedication to the god Pan the Ranger of the Forest (hyleskopos), who here appears with a different cult epithet, seems to 
have taken place towards the end of the hunting career of the dedicant. The hunting in this epigram includes targeting quadrupeds (the spear and foot traps), but it may have also targeted birds (hunting nets and nooses).

Perhaps the most famous epigram in this category of dedication of hunting equipment to deities is the epigram by Leonidas, writing in the 3rd century BCE, on the dedication to Pan of the nets of three brothers (6.13) [15]. The epigram reads as follows:

'Huntsman Pan, the three brothers dedicated these nets to you, each from a different chase: Pigres these from fowl, Damis these from beast and Clitor his from the denizens of the deep. In return for which send them easily caught game, to the first through the air, to the second through the woods, and to the third through the shore-water.' (translation by W.R. Paton)

This particular theme, of the three brothers dedicating three types of nets to Pan, had a very prominent afterlife. The same variation can be found in a number of other dedicatory epigrams included in the Palatine Anthology [16]. The popularity of the theme can be attested to by its inclusion on a fresco in the house of the Epigrams in Pompeii. The relevant room was decorated with five large frames, all depicting scenes from epigrams [17]. The dedicatory epigram of Leonidas was inscribed next to a mural depicting three young men, each with a net (CIL IV $3407=$ SEG $15.602=$ SEG 45.1455). The choice of the theme of the dedication of the hunting/fowling/fishing nets for the mural in this Pompeiian house implies that the epigram was well known among elite Roman circles in Pompeii and elsewhere.

Nets, traps, snares, and sticks with bird-lime, therefore, appear often in epigrams. Such references must reflect the reality of hunting techniques and equipment. At the same time, the funerary and dedicatory epigrams included in the Palatine Anthology are not necessarily 'real' epigrams for 'real' people. In many cases, they represent literary exercises by scholars, who show their artistic expertise and literary influences by composing epigrams on the same themes. Indeed, the many variations on Leonidas' epigram of the dedication of the three brothers shows exactly how popular such exercises of composition must have been. That said, the relationship between epigrams as literary exercises and epigrams for real people (such as inscribed epigrams on tombstones) is a very complex one; we cannot claim that there is a visible dividing line between the two types of epigrams [18]. Allusions in epigrams to hunting equipment cannot be explained solely as a popular literary theme. Rather, they should be placed within the context of references to hunting that did not belong to the elite hunting of big mammals and hares which was so favoured in our literary sources and hunting manuals. Indeed, epigrams are only one part of the ancient evidence that alludes to the use of snares, traps, and lime-glue for the hunting of birds [19].

Despite the problems with the nature of the evidence from epigrams, therefore, it is clear from a wide range of references that while hare, boar, and deer hunting dominated the literary narratives, there was a widespread practice that involved aspects of hunting that did not necessarily involve the elite. We have already seen how Plato disapproves of hunting on tilled and sacred land, at the edges of agricultural land, and during the night in his discussion of hunting practices and related regulations in his ideal city in his Laws [20]. The implication here is, I think, that trapping, night hunting, and hunting at the edges of agricultural land were relatively widespread practices and that is why the legislator in Plato felt the need to prohibit such activities. It is this particular point that I want to explore: the importance of the edges of the agricultural land as a suitable landscape for hunting.

\section{Hunting in the Eschatia}

In order to understand the role of the edges of agricultural land as an important locus for hunting, we need to place this type of landscape within the context of productive land. It is true that one of the most important generators of wealth in Greek antiquity was agricultural production. Indeed, considering the Greek mentality that stressed autarkeia (self-sufficiency) as an ideal for all units of the community (from the oikos, the household, to the polis), wealth produced by agriculture was 
the most socially accepted wealth. We now understand that the concept of 'self-sufficiency' was an ideal, and indeed, had little relevance to the ancient realities of economic production, consumption, and exchange. Agricultural land and produce may have been at the heart of the ancient Greek economy and ideals about economic self-sufficiency, but production beyond agriculture was also important. In this particular context, the edges of cultivated land, the eschatia in ancient sources, should also be seen as productive land [21]. In other words, the landscape beyond the agricultural tilled land, including the eschatia, was productive and economically important. It may not have been as productive as a fertile field in the plain, but it was able to generate produce of some sort or other. Bee-keeping, such as the famous honey of Hymettus, charcoal burning, wood produce, all were important products of the eschatia [22]. We should also add hunting was an important activity taking place in this un-cultivated (and therefore partly 'un-central') landscape. Hunting in the eschatia could be seen as another example of what Horden and Purcell call 'environmental opportunism', where human opportunity and ingenuity integrate environments into the productive system, even when such integration contributes only a small part to the nutritional aggregate [23].

In ancient Greek literary works, the term eschatia implies mostly the farthest part of a country, or indeed the border of a territory [24]. In Greek lexicographers, in particular, the term is associated with marginal land, or marginally cultivated land, close to the mountains or the sea [25]. We are on more secure ground with the epigraphic attestations of the term. A new fragment of the Athenian accounts from Delos, dated to 330/29, refers to an eschatia on Delos; this, surely, implies a piece of land by the edge of the littoral, by the sea [26]. It is the attestations of the term eschatia in the Rationes Centesimarum, the Athenian inscriptions recording the $1 \%$ tax paid on sales of public land and property, that has attracted most scholarly attention [27]. As Stephen Lambert observed, the term eschatia is remarkably frequent in these inscriptions [28]. While it is undeniable that the application of the label eschatia to pieces of land in these accounts does not necessarily imply a consistent use, the frequency of the term does seem to imply that such marginal land was often carefully demarcated, and belonged as property to either individuals or the state and communal entities (demes etc.) as public land. The term eschatia therefore did not necessarily imply land located at the border of the Athenian polis (that is, of the Attic territory), but rather, designated land that was 'at the edge' [29]. This, more often than not, implied a piece of land at the edge of cultivated territory; following the lexicographers, this could mean sometimes by the sea or by the hills/mountains. If we are right in understanding eschatia as land characterized by its marginality to good arable land, then the eschatia could be rocky and similar to the land designated as phelleus [30]. As we have already seen, such marginal land was not necessarily unproductive land, but could be an important part of local production networks.

So did hunting take place in the eschatia? Most narratives about mythical hunting focus on the mountains or the forest. But such mythical narratives also involve animals that were not necessarily often hunted in classical Greece. Heracles' lion hunting, for example, is unlikely to have been representative of an average hunting experience for most Greeks. It is true, we do hear of lions roaming in Macedonia (where presumably they would also be hunted), and we also have the spectacular story preserved in Pausanias of Polydamas, the Olympic winner of wrestling in 408, killing a wild lion on Mt Olympus with his bare hands [31]. I would argue, however, that despite the presence of such hunting stories in our literary sources, few Greeks in the classical period, especially in the southern Greek world, would have been engaged in such hunting experiences. The hunt of wild boar (kapros), contrary to that of lion, may have been relatively more widespread. But in contrast to modern times, when wild boar has proliferated in the southern Balkans due to mild winters, inter-breeding with domesticated boar (which produces a half-breed that breeds more piglets), and the abandonment of agriculture in many areas of modern Greece, it is unlikely that ancient boar in the classical period would enter cultivated zones [32]. So for boar and deer, which, along with hare, were the focus of elite hunt, the hunting territory would be predominantly the mountains and the forest.

Ancient narratives, therefore, pay attention to the mountains and the forest as the key territories where hunting would take place. The reason for this is their interest in the hunting of mammals, 
particularly deer, boar, and hare, which represented an elite form of hunting. The edge of the cultivated land, the eschatia, is not often discussed in our sources as a hunting landscape. Plato's prohibition, however, of hunting at the edge of cultivated land seems to imply that hunting did take place in such areas. Indeed, if we look closely at our ancient sources, we can see that hunting at the edge of cultivated land is occasionally mentioned. Both Xenophon's and Arrian's Cynegetica, which are key sources for elite attitudes and ideology related to hunting, stress the difficulty of hunting hares on rocky ground or on hills [33]. Both authors use the word phelleus to designate the rocky land where the hunting of hare becomes difficult; as we have already seen, the land designated as phelleus shares many similarities with the eschatia in our Athenian sources. It is very likely, therefore, that hunting in the eschatia is among the landscapes that Xenophon and Arrian have in mind when discussing the hunting of hares.

Indeed, there is enough evidence, especially about bird hunting, to suggest that the eschatia, the edge of cultivated land, was ideal for other forms of hunting, such as bird hunting, which did not attract the approval of ancient writers such as Xenophon, Plato, or Arrian. The practice of using lime-glue and nets to capture birds, in particular, was more productive at the edge of cultivated land rather than deep in the forest or up in the mountains. We have one remarkable piece of evidence that does suggest that opportunistic hunting within cultivated land, or at the edge of cultivated land, was an important feature of bird hunting. A letter of Alciphron, included in his second book of Letters of Farmers, describes how a farmer put glue directly on the tree itself in order to capture birds (2.27). The setting is particularly important: the farmer in this letter complains that the winter is severe and everything is covered by snow, making any agricultural work impossible. While he was sitting idle in his cabin, he saw a flock of blackbirds (kopsichos) and thrushes (kichle); he immediately set out and put lime-glue (ixos) on the wild pear-tree branches. The exercise was very successful: the farmer writes to his friend that he is sending him twenty-five of the birds, implying that the overall catch was much larger [34]. This is an important source for the practice of putting lime-glue on the tree itself rather than on sticks that were then placed at strategic locations [35]. The farmer in this letter is not presented as a dedicated professional hunter; rather, the hunting of birds with the use of lime-glue should be understood as a supplementary addition to his overall agricultural production. The capture of birds in such large numbers becomes especially important because of the time of year: in the winter, the capture of animals became more difficult, and therefore, the calorific importance of hunted birds even more significant. In addition, blackbirds, and especially thrushes, were considered a delicacy and were sought after in the ancient world [36]. This particular source highlights the importance of opportunity for the hunt: the farmer did not set out to go hunting, but spotted the opportunity to capture birds and immediately proceeded to do so using lime-glue (and he therefore engaged in a form of hunting of which Plato would not approve). The location is also important: the farmer 'peeped out of his cabin' ( $\pi \rho \circ \kappa \dot{u} \psi \alpha \varsigma \delta \tilde{\eta} \tau \alpha \tau \tilde{\eta} \varsigma \kappa \alpha \lambda \dot{u} \beta \eta \varsigma$ ) and he spotted the flock of birds. The word cabin or hut (kalybe) is significant: it provides an important rustic setting for the episode, and implies a certain degree of poverty. The hunt itself takes place exactly on the borders of cultivated land, on the eschatia, even though this specific word is not used by Alciphron. It must be close to the farmer's cabin so that the farmer can spot the opportunity, but at the same time, the presence of a wild-pear tree (achras) implies a not-fully-cultivated landscape. I suggest that the wild pear tree was located at the borders of the farmer's land, and therefore, created a marker between the cultivated landscape and the wilderness beyond.

I have used Alciphron's letter as a straightforward source for actual practices of hunting. Yet, while I believe that we can use it in this manner, the letter itself has many additional layers. Alciphron is engaging in developing a genre that has strong inter-textual elements [37]; he creatively uses a number of previous authors and genres, among which, at least for his second book that includes the letters of farmers, Theocritus is perhaps one of the most important. Recent work on Alciphron has underlined how Alciphron is interested in hierarchies of statuses, and how he creates a literary construct that focuses on low-status individuals (especially in the second book) [38]. Alciphron's interest in low 
status (or low class) individuals is particularly important. Such a focus may have to do with the complex interplay between Alciphron and the kind of literature and genre he is engaging with; but as Alciphron is using classical Greek texts (such as Menander), the image of the farmer engaged in opportunistic hunting of birds seems to tap into realities of actual practices. The specific reference to lime-glue applied to the tree directly (rather than to sticks) seems to imply intimate knowledge of an actual practice. Despite, therefore, the multi-layered allusions and the complex construction of reality in Alciphron's letters, I do think it is valid to use it as a source that highlights low-class hunting experiences based on marginal location and opportunity.

\section{Hunting and the Market}

Location and opportunity, therefore, mattered when it came to hunting. Indeed, the distance of the hunting landscapes from urban centres was a very important parameter, and one which, unfortunately, tends to be ignored in modern works on hunting. My understanding of hunting includes, as I have already stated, practices that may be understood as widespread, involving the community beyond the elite circles. In that context, the importance of the market is paramount. The kind of hunting I am looking at involved procuring game for the market, and did not simply aim at consumption by the hunters and their families and friends. We know that game was sold and bought in the market. The Athenian agora had a space allocated for the selling of birds, which must have included both live birds and game procured through hunting [40]. We also have a great number of references in Old Comedy, mostly preserved as fragments in Athenaeus' Philosophers at Dinner, referring to game bought and sold in the market (Athen. 694b-656a). Indeed, our classical sources include an impressively large list of game products consumed in Athens; these must have been the result of hunting. In addition to boar, hare, and deer, we have references to francolin (attagas), goose, duck, coot (phalaris), purple coot (porphyrion), pigeon, partridge and of course, thrushes and blackbirds, to name a few of a very long list of game [41]. If the ancient Athenians were able to buy all these different types of game in the market, then surely the implication is that there was considerable hunting taking place in the Athenian countryside. The selling of birds, in particular, was the end-product of a type of hunting that did not involve the elite. I would argue that the selling of hare in the market was also the result of non-elite hunting. I doubt that young men chasing hare with specialized dogs, that is, men engaged in the type of hunting that Xenophon pays attention to, would end up selling their catch in the market. It seems far more likely that game caught as a result of elite men going on a hunt would have been consumed by the hunters themselves.

The preservation of game as also an issue that needed to be taken into consideration. One of Plutarch's questions in his Quaestiones Convivales (Moralia 657f-659) is 'Why Flesh Stinks Sooner When Exposed to the Moon than to the Sun'. Plutarch's answer to this question includes a section about the best way to preserve meat; the answer is to put a bronze nail through the carcass to delay putrefaction. Plutarch's solution to the problem does not work, but the question itself shows that the swift transfer of game from the location of hunting to the centre of consumption (occasionally via the market and the process of exchange) was of paramount importance.

If we consider, therefore, the importance of the market for hunting, and of the logistics of transferring game from the hunting location to the place of exchange and finally the place of consumption, the importance of the eschatia, the edge of cultivated land, becomes even more visible. Hunting in the eschatia provided many advantages for hunting: it was opportunistic (as in the letter by Alciphron where the farmer spots the birds sitting on a tree from his own cabin), required minimum effort in terms of crossing distances (compared to the forest or the mountains), allowed access to game that could be profitable in the market (such as the delicious thrushes and blackbirds), and made the transport of game easier to manage. 


\section{Conclusions}

Our written sources, with their ideological viewpoint, stress elite ideology and practice, often obscuring the importance and widespread practice of hunting by the non-elite. Non-elite hunting used nets, traps, snares, and lime-glue either on sticks or applied on the tree itself (in the case of birds), and could be practiced at the edge of cultivated land. The importance of markets, and proximity to markets, is another aspect that we need to take into consideration when examining the importance of hunting as a non-elite practice. My aim is to place hunting firmly in a historical account that explores the role of the environment in human activity: in that sense, ancient sources and their elite ideology and modern narratives that stress the role of hunting as a rite of passage for the young to prepare for war and citizenship do not help us understand the complex interplay between humans, animals, and the environment.

Funding: This research received no external funding.

Acknowledgments: I would like to thank Giorgos Papantoniou and Athanasios K. Vionis for their kind invitation to participate in their panel on 'Central places and un-central landscapes: political economies and natural resources in the longue durée', in the 19th International Congress of Classical Archaeology in Bonn/Cologne in May 2018 and for their support and intellectual generosity.

Conflicts of Interest: The author declare no conflict of interest.

\section{References and Notes}

1. Horden, P.; Purcell, N. The Corrupting Sea; Blackwell: Oxford, UK, 2000; ISBN 978-0631218906.

2. Constantakopoulou, C. The Dance of the Islands. Insularity, Networks, the Athenian Empire, and the Aegean World; Oxford University Press: Oxford, UK, 2007; ISBN 978-0199215959. Constantakopoulou, C. Beyond the polis: Island koina and other non-polis entities in the Aegean. REA 2012, 114, 301-331.

3. Davis, K. Intersectionality as buzzword. A sociology of science perspective on what makes a feminist theory successful. Fem. Theor. 2008, 9, 67-86. [CrossRef]

4. Phillips, A.A.; Willcock, M.M. Xenophon Cynegeticus (On Hunting) and Arrian Cynegeticus (On Hunting). In Xenophon and Arrian On Hunting; Aris and Phillips: Warminster, UK, 1999; ISBN 9780856678068.

5. Oppian's (of Apamea) Cynegetica, a hexameter poem, written in the 3rd century CE. See Bartley, A.N. Stories from the mountain, Stories from the sea. In The Digressions and Similes of Oppian's Halieutica and the Cynegetica; Vandenhoeck \& Ruprecht: Göttingen, Germany, 2003; ISBN 978-3525252499. Blaskiewicz, M.

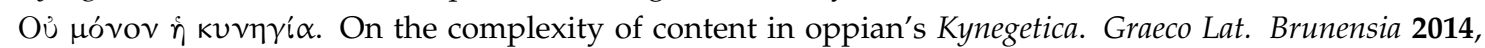
19, 27-40. On Arrian and Oppian see L'Allier, L. L'art de la chasse; Les Belles Lettres: Paris, France, 2009; ISBN 9782251339559.Nemesianus also composed a poem on hunting (Cynegetica) in the 3rd century CE. See Williams, H.J. The Eclogues and Cynegetica of Nemesianus; Brill: Leiden, The Netherlands, 1986; ISBN 978-9004074866. Jakobi, R. Nemesianus, Cynegetica: Edition und Kommentar; De Gruyter: Berlin, Germany, 2014; ISBN 9783110265996.Grattius wrote in the Augustan period a hexameter poem also called Cynegetica. See Sestili, A. Il Cinegetico: Trattato sulla caccia di Grazio Falisco; Introduzione, Traduzione e Note; Società editrice Dante Alighieri: Rome, Italy, 2011; ISBN 9788853437051. Green, S.J. (Ed.) Grattius: Hunting an Augustan Poet; Oxford University Press: Oxford, UK, 2018; ISBN 9780198789017.

6. In Plutarch (Alcibiades 9), Alcibiades is said to have bought his dog for 7000dr, a truly astonishing amount (half a drachma was the daily wage for an unskilled labourer). The dog is not specified as a hunting dog in the text, but considering Alcibiades' ostentatious behavior, it is very likely that it was a hunting dog. Athenaeus reports that Polycrates, the tyrant of Samos, imported dogs from Epirus, Molossia, and Sparta: The dogs are not specified as hunting dogs, but it is difficult to see what other type they could be (Athenaeus 12. 540d, quoting Clytus FGrH 490 F2 and Alexis FGrH 539 F2). Molossian and Spartan breeds were famous in antiquity for their hunting skills: See Phillips, A.A.; Willcock, M.M. Xenophon and Arrian On Hunting; Aris and Phillips: Warminster, UK, 1999; pp. 15-18. ISBN 9780856678068. Lane Fox, R. Ancient Hunting: From Homer to Polybios. In Human Landscapes in Classical Antiquity: Environment and Culture; Shipley, G., Salmon, J., Eds.; Routledge: London, UK, 1996; pp. 118-153. ISBN 9780415107556. Barbara, S. Les chiens de l' Epyllium Diomedis (V.8-19). Quelques remarques sur la literature cynégétique à l'époque hellénistique. In Chasses Antiques: Pratiques et Représentations Dans le Monde Gréco-Romain, IIIe Siècle av.-IVe Siècle Apr. 
J.-C.; Trinquier, J., Vendries, C., Eds.; Presses Universitaires de Rennes: Rennes, France, 2009; pp. 163-176. ISBN 9782753708354.

7. For hunting iconography and related interpretations see Schnapp, A. Le Chasseur et la Cité: Chasse et Érotique en Grèce Ancienne; Albin Michel: Paris, France, 1997; ISBN 2226064753. Barringer, J. The Hunt in Ancient Greece; John Hopkins University Press: Baltimore, MD, USA, 2002; ISBN 9780801866562.

8. Anderson, J.K. Hunting in the Ancient World; University of California Press: Berkeley, CA, USA, 1985; ISBN 0520051971. Lane Fox, R. Ancient hunting: From homer to polybios. In Human Landscapes in Classical Antiquity: Environment and Culture; Shipley, G., Salmon, J., Eds.; Routledge: London, UK, 1996; pp. 118-153. ISBN 9780415107556.

9. The seminal work that explored mythical accounts of hunting as rites of passage is Vidal-Naquet, P. The Black Hunter: Forms of Thought and Forms of Society in the Greek World; John Hopkins University Press: Baltimore, MD, USA, 1986; ISBN 0801832519.

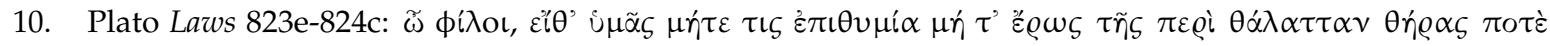

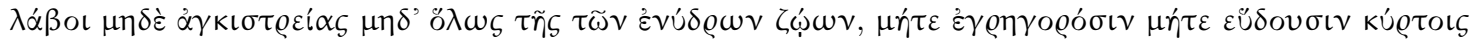

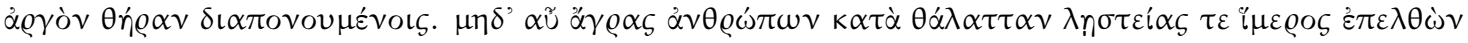

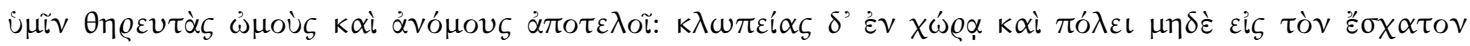

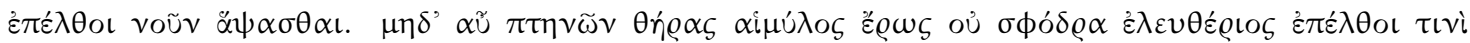

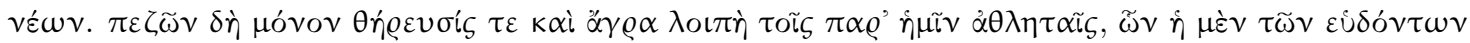

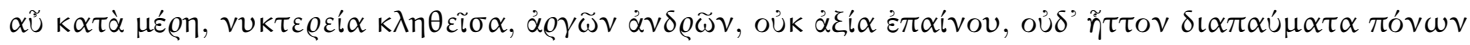

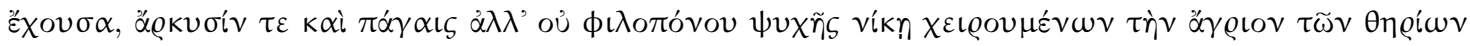

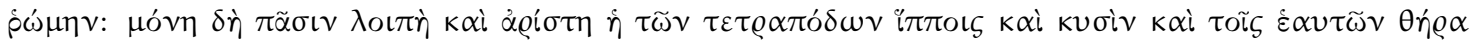

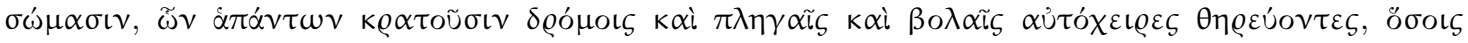

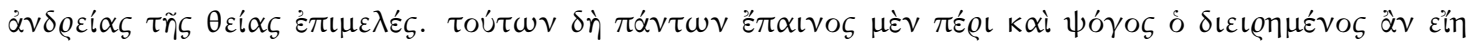

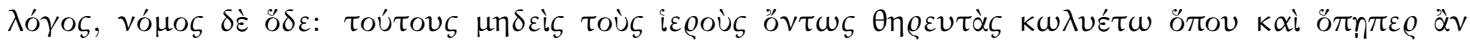

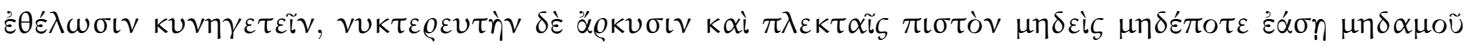

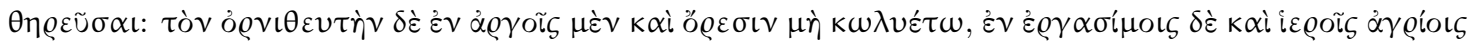

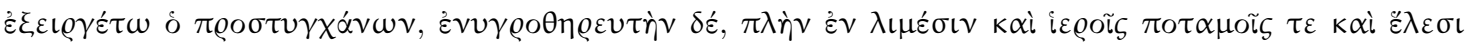

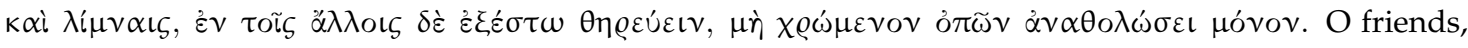
we will say to them, may no desire or love of hunting in the sea, or of angling or of catching the creatures in the waters, ever take possession of you, either when you are awake or when you are asleep, by hook or with weels, which latter is a very lazy contrivance; and let not any desire of catching men and of piracy by sea enter into your souls and make you cruel and lawless hunters. And as to the desire of thieving in town or country, may it never enter into your most passing thoughts; nor let the insidious fancy of catching birds, which is hardly worthy of freemen, come into the head of any youth. There remains therefore for our athletes only the hunting and catching of land animals, of which the one sort is called hunting by night, in which the hunters sleep in turn and are lazy; this is not to be commended any more than that which has intervals of rest, in which the wild strength of beasts is subdued by nets and snares, and not by the victory of a laborious spirit. Thus, only the best kind of hunting is allowed at all-That of quadrupeds, which is carried on with horses and dogs and men's own persons, and they get the victory over the animals by running them down and striking them and hurling at them, those who have a care of godlike manhood taking them with their own hands. The praise and blame which is assigned to all these things has now been declared; and let the law be as follows: - Let no one hinder these who verily are sacred hunters from following the chase wherever and whithersoever they will; but the hunter by night, who trusts to his nets and gins, shall not be allowed to hunt anywhere. The fowler in the mountains and waste places shall be permitted, but on cultivated ground and on consecrated wilds he shall not be permitted; and any one who meets him may stop him. As to the hunter in waters, he may hunt anywhere except in harbours or sacred streams or marshes or pools, provided only that he do not pollute the water with poisonous juices. (translation by Benjamin Jowett). Detienne, M.; Vernant, J.-P. Cunning Intelligence in Greek Culture and Society; Harvester Press: Atlantic Highlands, NJ, USA, 1978; p. 33. ISBN 0391007408.

11. For a full discussion of hunting references in Greek epigrams see Prioux, E. Le motif de la chasse dans les epigrammes de 1' Anthologie grecque. In Chasses Antiques: Pratiques et Représentations dans le Monde Gréco-Romain, IIIe siècle av.-IVe siècle apr. J.-C.; Trinquier, J., Vendries, C., Eds.; Presses Universitaires de Rennes: Rennes, France, 2009; pp. 177-194. ISBN 9782753708354. Icard, N.; Linant de Bellefonds, P. La chasse 
dans le monde grec et romain. In Thesaurus Cultus et Rituum Antiquorum; Getty Publications: Los Angeles, CA, USA, 2004-2014; Volume 6, pp. 361-370. ISBN 9781606060735.

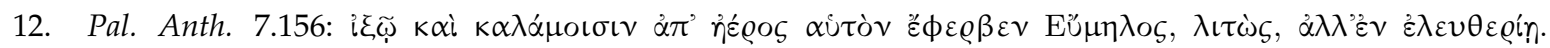

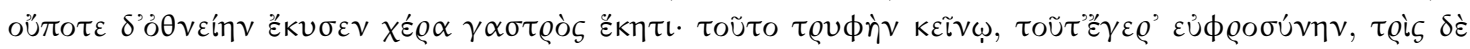

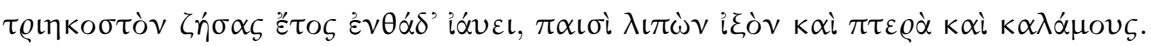

13. Pal. Anth. 6.109: 'Craugis the huntsman, son of Neolaidas, an Arcadian of Orchomenus, gives to thee,

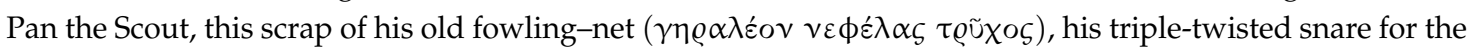

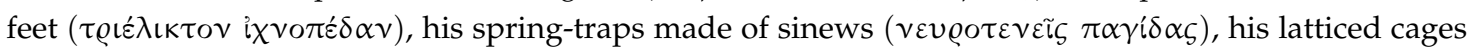

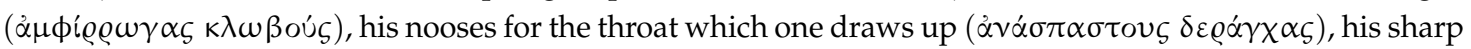

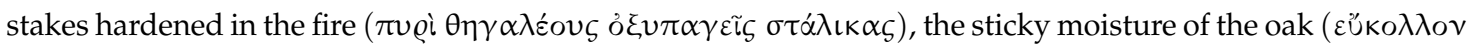

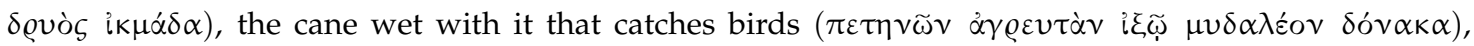

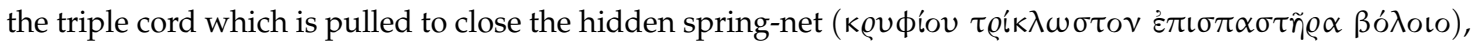

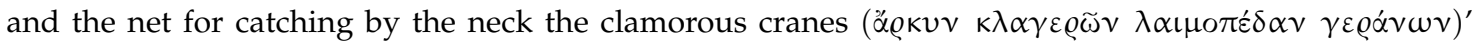
(translation by W.R. Paton).

14. Pal. Anth. 6.107: 'The huntsman Gelo dedicates to Pan, the ranger of the forest, me, his spear $(\lambda o ́ \gamma \chi \eta v)$, the edge of which time has worn by use, also the old rags of his twisted hunting nets ( $\lambda i v \omega v \pi \circ \lambda v \sigma \tau \varrho o ́ \phi \omega \nu$

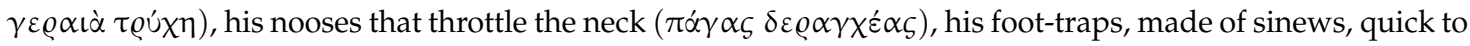

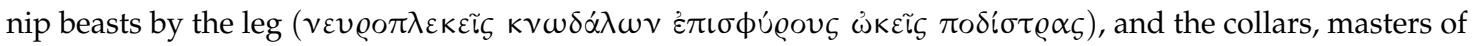
his dogs' necks; for time has overcome his strength and he has now renounced wandering over the hills' (translation by W.R. Paton).

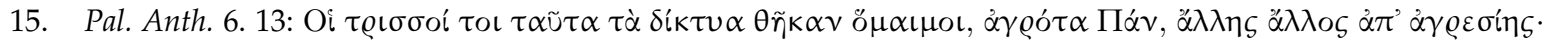

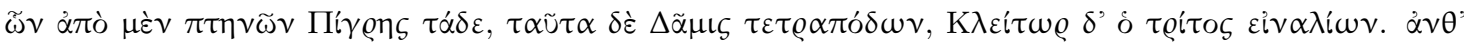

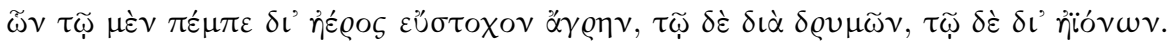

16. Pal. Anth. 6.14, by Antipater of Sidon, four variations by Archias (6.16, 6.179, 6.180, and 6.181), and more: See $6.11,6.12,6.15$, and 6.182-187. On Leonidas' epigram of the three brothers and the subsequent variations see Longo, O. Leonid: AP VI, 13 e la sua fortuna (cacciatori, uccellatori, pescatori). In Museum Criticum 1986-1987 21-22, pp. 277-302. Gutzwiller, K.J. Poetic Garlands. Hellenistic Epigrams in Context; University of California Press: Berkeley, CA, USA, 1998; pp. 241-245. ISBN 9780520208579.

17. Leach, E.W. The Rhetoric of Space: Literary and Artistic Representations of Landscape in Republican and Augustan Rome; Princeton University Press; Princeton, NJ, USA; 1988; pp. 219-222. ISBN 0691042373. Bergman, B. A Painted Garland: Waving Words and Images in the House of Epigrams in Pompeii. In Art and Inscriptions in the Ancient World; Leader-Newby, R., Newby, Z., Eds.; Cambridge University Press; Cambridge, UK; 2007; pp. 60-101. ISBN 9780521868518. Original publication in Dilthey, K. Dipinti pompeiani accompagnati d'epigrammi greci. Annali dell' Instituto di Corrispondenza Archaeologica 1876, 46, 294-314.

18. Gutzwiller, K.J. Poetic Garlands. Hellenistic Epigrams in Context; University of California Press: Berkeley, CA, USA, 1998; ISBN 9780520208579. Bruss, J.S. Hidden Presences: Monuments, Gravesites and Corpses in Greek Funerary Epigram; Peeters: Leuven, Belgium, 2005; ISBN 9042916419.

19. Böhr, E. Vogelfang mit Leim und Kauz. AA 1992-1994, pp. 573-583. Vendries, C. L' auceps, les gluaux et l'appeau. À propos de la ruse et de l'habileté du chasseur d'oiseaux. In Chasses Antiques: Pratiques et Représentations dans le Monde Gréco-Romain, IIIe siècle av.-IVe siècle apr. J.-C.; Trinquier, J., Vendries, C., Eds.; Presses Universitaires de Rennes: Rennes, France, 2009; pp. 119-140. ISBN 9782753708354.

20. See note 10 above.

21. Forbes, H. The Uses of the Uncultivated Landscape in Modern Greece: A Pointer to the Value of the Wilderness in Antiquity? In Human Landscapes in Classical Antiquity: Environment and Culture; Shipley, G., Salmon, J., Eds.; Routledge: London, UK, 1996; pp. 68-97. ISBN 9780415107556. Davies, J.K. Classical Greece: Production. In The Cambridge Economic History of the Greco-Roman World; Scheidel, W., Morris, I., Saller, R., Eds.; Cambridge University Press: Cambridge, UK, 2007; pp. 339-341. ISBN 9780521780527.

22. Honey from Hymettus in Aristophanes Wasps 878, fragments of Old Comedy, such as Aristophanes F581 [K-A] and Eubulus F74 [K-A], and Pliny NH 11.34 and 21.57. Jones, J.E. Hives and Honey of Hymettus. Beekeeping in Ancient Greece. Archaeology 1976, 29, 80-91. Dalby, A. Siren Feasts. A History of Food and Gastronomy in Greece; Routledge: London, UK, 1996; p. 65. ISBN 041515672. Moreno, A. Feeding the Democracy: The Athenian Grain Supply in the 5th and 4th Centuries BC; Oxford University Press: Oxford, UK, 1997; pp. 66-68. ISBN 9780199228409. Charcoal and wood burning: Veal, R. The Politics and Economics of 
Ancient Forests: Timber and Fuel as Levers of Greco-Roman Control. In Economie et Inégalité. Ressources, Échanges et Pouvoir dans L'Antiquité Classique; Derron, P., Ed.; Fondation Hardt Pour L'étude de L'antiquité Classique: Vandoeuvres, Switzerland, 2017; pp. 317-368. ISBN 9782600007634.

23. Horden, P.; Purcell, N. The Corrupting Sea; Blackwell: Oxford, UK, 2000; p. 80. ISBN 978-0631218906.

24. For a discussion on the term eschatia and its meaning: Lewis, D.M. The Athenian Rationes Centesimarum. In Problèmes de la Terre en Grèce Ancienne; Finley, M., Ed.; Mouton: Paris, France, 1973; pp. 187-212. ISBN 2713200016. Casevitz, M. Sur eschatia. Histoire du mot. In Frontières Terrestres, Frontiers Celestes Dans l' Antiquité; Rousselle, A., Ed.; Presses universitaires de Perpignan: Paris, France, 1995; pp. 19-30. ISBN 2908912236. Jameson, M. Attic eschatia. In Ancient History Matters; Ascani, K., Ed.; L'Erma di Bretschneider: Rome, Italy, 2002; pp. 63-68. ISBN 8882651908.

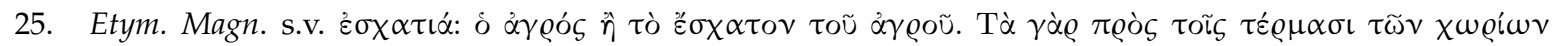

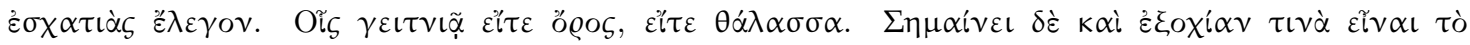

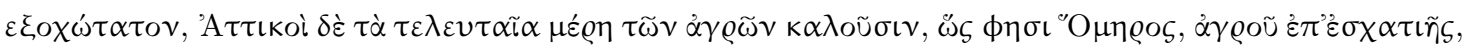

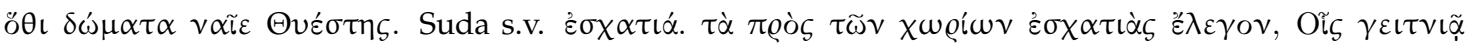

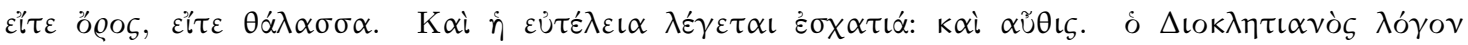

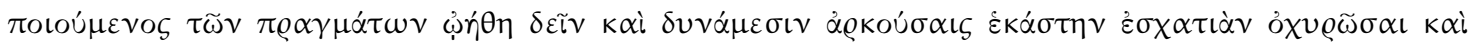

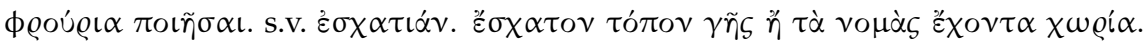

26. Walbank, M.B. A Record of the Athenian Administration of Delos. Hesperia 2014, 83, 495-502. [CrossRef]

27. Lewis, D.M. The Athenian rationes centesimarum. In Problèmes de la Terre en Grèce Ancienne; Finley, M., Ed.; Mouton: Paris, France, 1973; pp. 187-212. Lambert, S. Rationes Centesimarum: Sales of Public Land in Lykourgan Athens; J.C. Gieben: Amsterdam, The Netherlands, 1997; ISBN 9789050631570. Papazarkadas, N. Sacred and Public Land in Ancient Athens; Oxford University Press: Oxford, UK, 2011; pp. 134-135. ISBN 9780199694006.

28. $26 \%$ of the properties in the Rationes Centesimarum are designated as eschatia: Lambert, S. Rationes Centesimarum: Sales of Public Land in Lykourgan Athens; J.C. Gieben: Amsterdam, The Netherlands, 1997; pp. 225-229. ISBN 9789050631570. Papazarkadas, N. Sacred and Public Land in Ancient Athens; Oxford University PressL: Oxford, UK, 2011; p. 134. ISBN 9780199694006.

29. Lewis, D.M. The Athenian rationes centesimarum. In Problèmes de la Terre en Grèce Ancienne; Finley, M., Ed.; Mouton: Paris, France, 1973; pp. 201-202. Lambert, S. Rationes Centesimarum: Sales of Public Land in Lykourgan Athens; J.C. Gieben: Amsterdam, The Netherlands, 1997; p. 225. ISBN 9789050631570. Jameson, M. Attic eschatia. In Ancient History Matters; Ascani, K., Ed.; L'Erma di Bretschneider: Rome, Italy, 2002; pp. 63-68. ISBN 8882651908. Harris, E.M. The legal foundations of economic growth. In The Ancient Greek Economy. Markets, Households and City-States; Harris, E.M., Lewis, D.M., Woolmer, M., Eds.; Cambridge University Press: Cambridge, UK, 2016; p. 121. ISBN 9781107035881.

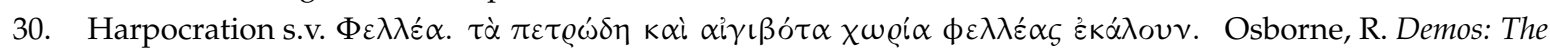
Discovery of Classical Attica; Cambridge University Press: Cambridge, UK, 1985; p. 20. ISBN 0521267765. Krasilnikoff, J.A. Attic $\phi \varepsilon \lambda \lambda \varepsilon \cup ́$ s. Some Observations on Marginal Land and Rural Strategies in the Classical Period. ZPE 2008, 167, 37-49.

31. Aristotle Hist. Anim. $579 \mathrm{~b} 6$ and $606 \mathrm{~b} 14$ comments on the scarcity of lions in southern Greece, contrary to their presence in Macedonia. Herodotus 7.125 mentions lions attacking the camels crossing Macedonia as part of Xerxes' army. Pausanias 6.5.4-5 on the story of Polydamas killing a wild lion on Mt Olympus. Alexander also hunted lions in Plutarch, Life of Alexander 40.3.

32. Wild boar entering cultivated zones and urban areas in modern Greece has become a problem in the last 10 years or so, after some hunters' associations released a number of wild boars in the wild in order to increase the animal population, which would then be suitable for hunting. The change of climate towards milder winters, as well as the abandonment of agricultural land due to shortage of labour and the minimizing of profit, has contributed to a proliferation of the number of wild boars that roam the countryside. See $\Pi \omega \dot{ } \varsigma$

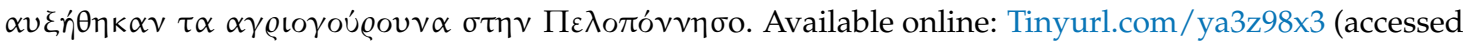

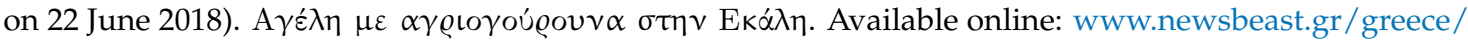
arthro/3624278/ageli-me-agriogourouna-stin-ekali (accessed on 22 June 2018).

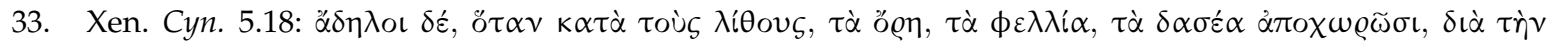
óóx@oเ $\alpha v$. [Hares are] invisible, though, when they run off among rocks, on mountains, stony ground, in

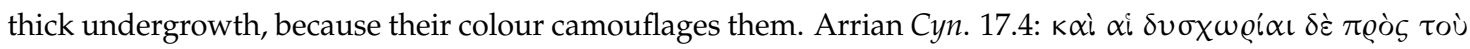

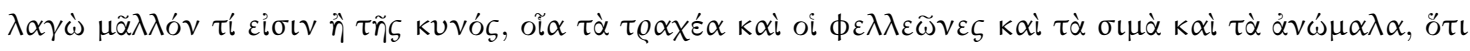




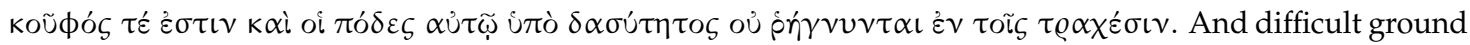
favours the hare more than the hound, where it is rough and stony, uphill and uneven, because she is light and her feet being hairy are not torn on rough surfaces. (translations by A.A. Phillips and M.M. Willcock).

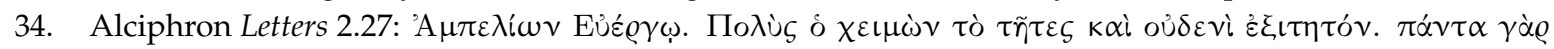

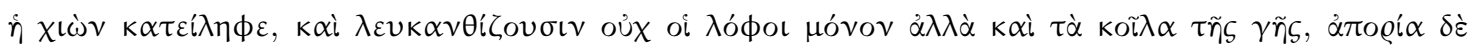

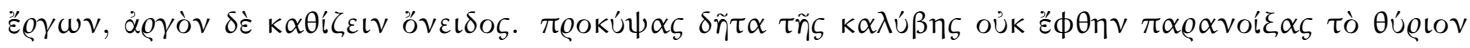

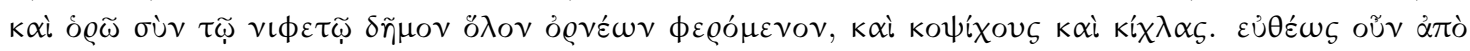

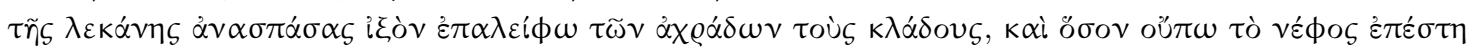

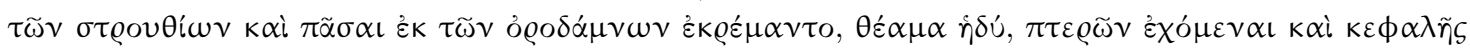

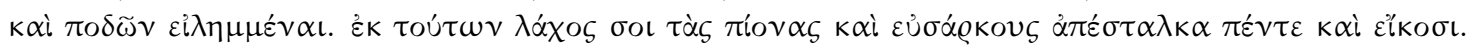

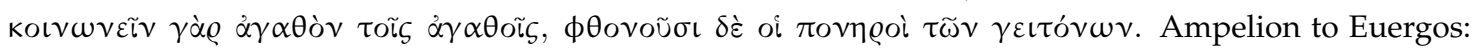
The winter is severe this year, and nobody can walk abroad. For everything is wrapped in snow; and not only the hills but also the valleys blossom with white. There is no work that can be done, and yet it is a shame to sit idle. Well, I peeped out from my cabin, and I had hardly opened my door a crack when I saw along with the snow a whole tribe of birds soaring aloft, both blackbirds and thrushes. So at once I dipped birdlime from the pot and smeared the wild pear branches; and almost before the cloud of birds settled, there they were all hanging from the boughs-A lovely spectacle-Adhering by their wings, and caught head and foot. Five-and-twenty of them I have sent to you as your share, the fat and well-fleshed birds; for it's good for good neighbours to share their possessions, though bad neighbours begrudge them (translation by A. Rogers Benner and F.H. Fobes).

35. Vendries, C. L' auceps, les gluaux et l'appeau. À propos de la ruse et de l'habileté du chasseur d'oiseaux. In Chasses Antiques: Pratiques et Représentations dans le Monde Gréco-Romain, IIIe Siècle av.-IVe Siècle Apr. J.-C.; Trinquier, J., Vendries, C., Eds.; Presses Universitaires de Rennes: Rennes, France, 2009; p. 123. ISBN 9782753708354.

36. Many references in Old Comedy, such as Aristophanes Acharnians 1116-7, Clouds 339, Peace 1149, 1195, Telecleides Amphictyons F1 (K-A) quoted in Athenaeus 6.268b-c. Geoffrey Arnott, W. Birds in the Ancient World from A to Z; Routledge: London, UK, 2007; pp. 94-95. ISBN 9780415540889.

37. König, J. Alciphron's epistolarity. In Ancient Letters: Classical and Late Antique Epistolography; Morello, R., Morrison, A.D., Eds.; Oxford University Press: Oxford UK, 2007; pp. 257-282. ISBN 9780199203956. Hodkinson, O. Epistolography. In Oxford Handbook of the Second Sophistic; Richter, D.S., Johnson, W.A., Eds.; Oxford University Press: Oxford, UK, 2017; pp. 509-529. ISBN 9780199837472.

38. Hodkinson, O. Attic Idylls. Hierarchies of herdsmen and social status in Alciphron and Longus. JHS 2012, 132, 41-53. Available online: www.jstor.org/stable/41722253 (accessed on 20 June 2018). [CrossRef]

39. The main evidence is Aristophanes' Birds 13-14 with Dunbar, N. Aristophanes Birds; Oxford University Press: Oxford, UK, 1995; p. 139. ISBN 9780198150831.

40. Wycherley, R.E. The Athenian Agora III. Literary and Epigraphical Testimonia; American School of Classical Studies at Athens: Princeton, NJ, USA, 1957., for the evidence of a bird market in the Athenian agora. Aristophanes Birds 529-531 also alludes to the selling of birds in the agora (but the passage has also erotic connotations). Nicarchus' epigram in the Palatine Anthology refers to ten thrushes being sold for a drachma (Pal. Anth. 11.96).

41. For a full discussion see Chandezon, C. Le gibier dans le monde grec. Rôles alimentaire, économique et social. In Chasses antiques: Pratiques et Représentations Dans le Monde Gréco-Romain, IIIe Siècle av.-IVe Siècle apr. J.-C.; Trinquier, J., Vendries, C., Eds.; Presses Universitaires de Rennes: Rennes, France, 2009; pp. 85-95. ISBN 9782753708354. Lewis, D.M. Commodities in Classical Athens: The Evidence of Old Comedy. In The Ancient Greek Economy. Markets, Households, and City-States; Harris, E.M., Lewis, D.M., Woolmer, M., Eds.; Cambridge University Press: Cambridge, UK, 2016; pp. 381-398. ISBN 9781107035881. Chandezon, C. Animals, Meat and Alimentary By-products: Patterns of Production and Consumption. In A Companion to Food in the Ancient World; Wilkins, J., Nadeau, R., Eds.; Wiley Blackwell: Oxford, UK, 2015; pp. 135-146. ISBN 9781405179409.

(C) 2018 by the author. Licensee MDPI, Basel, Switzerland. This article is an open access article distributed under the terms and conditions of the Creative Commons Attribution (CC BY) license (http://creativecommons.org/licenses/by/4.0/). 